\title{
Does Monetary Policy Boost Economic Growth? The Case of Small Open Economy
}

\author{
Javid Aliyev $^{1}$, Shahriyar Mukhtarov ${ }^{1,2}$, Khanlar Haydarov ${ }^{3,4} \&$ Murad Isgandarov $^{3}$ \\ ${ }^{1}$ Department of World Economy, Baku Engineering University, Baku, Azerbaijan \\ ${ }^{2}$ UNEC Empirical Research Center, Azerbaijan State University of Economics (UNEC), Baku, Azerbaijan \\ ${ }^{3}$ Department of Public Administration, Baku Engineering University, Baku, Azerbaijan \\ ${ }^{4}$ Department of Business Administration, Baku Engineering University, Baku, Azerbaijan \\ Correspondence: Shahriyar Mukhtarov, Department of World Economy, Baku Engineering University, Baku \\ AZ0101, Azerbaijan. E-mail: smuxtarov@beu.edu.az
}

Received: April 29, 2020

doi:10.5430/rwe.v11n3p216
Accepted: June 13, 2020

Online Published: June 18, 2020

URL: https://doi.org/10.5430/rwe.v11n3p216

\begin{abstract}
The main aim of this paper is to investigate the impact of monetary policy tools on economic growth in Azerbaijan during 2005-2018 using the Vector Error Correction Model (VECM). Also, different co-integration methods, namely, Johansen, DOLS, FMOLS and CCR were utilized for the robustness test. The outcomes of the different co-integration methods are consistent with one another and confirm the existence of long-run relationships among variables. Furthermore, the estimation results of VECM show that the monetary base and exchange rate have a positive and statistically significant impact on economic growth in the long-run, while the discount rate is insignificant. The paper concludes that the monetary base and exchange rate should be promoted by policymakers over other monetary policy tools during monetary policy implementation toward stimulating economic growth.
\end{abstract}

Keywords: monetary policy, economic growth, cointegration, VECM, Azerbaijan

\section{Introduction}

It is an obvious fact that the ultimate objective of a government is to achieve lower unemployment, sustainable economic growth and stability of the prices (Mankiw, 2012). In order to obtain these desired results, a government should utilize some economic policies. Monetary policy is one of those economic policies. In economic theory, the views of economic schools on monetary policy differ. In particular, the debate on whether monetary and fiscal policy is effective on economic activities is still an ongoing thing (Schmitt-Grohe et. al., 2007). Classical economists claim that the economy has always reached full employment. They support that money is ineffective in affecting the real economy, it only affects the overall level of prices. Keynesian economists state that money can affect both the real economy and the general level of prices. Today, the general debate among economic schools is in this direction. They try to examine how monetary policy affects economic growth in various conditions. In other words, they want to determine how the impact of monetary policy on the economic prosperity changes in different nations. Therefore, central banks and their conduct toward influencing economic conditions through monetary policy is the main target for many studies (Gul et. al., 2014).

In order to be capable of implementing monetary policy, the Central Bank of the Republic of Azerbaijan was founded in 1992. The main aim was to gain sustainable economic growth and to preserve the stability of prices through control over inflation. By using several monetary policy tools such as open market operations, required reserve ration, discount rate and exchange rate Azerbaijan central bank attempts to apply contractionary or expansionary monetary policy. By means of this policy, it aims to affect aggregate supply, aggregate demands and balance of trade. (Mammadov, 2013)

Due to the abundant oil reserves and openness, oil exports of the country rose significantly after the contract of the century. Consequently, this situation led the country's GDP to increase year by year. Eventually, economic conditions in the country highly improved and significant economic growth was observed for several years. However, the drop in oil prices in the international market had its detrimental effects on Azerbaijan economy too. As a result of this incident, recession has been observed in recent years. Currently, both monetary and fiscal policies are being 
implemented to obtain the desired level of economic growth in the economy (Mukhtarov et. al., 2018).

Regarding the carrying out proper monetary policy in the economy, several questions emerge: Are the monetary policies implemented by Central Banks efficient and effective enough to alter economic situations? Which tools of monetary policy are more effective in terms of stimulating economic growth? To what extent, should tools of monetary policy be utilized?

With the goal of finding answers to above mentioned hypotheses, this study examines the existence of the link between monetary policy and economic growth in Azerbaijan. The main goal of the study is to measure the effectiveness of monetary policy in Azerbaijan by using several econometric methods such as VECM, DOLS, FOMLS and finding out which specific monetary policy tool is more effective to be implemented by the Central Bank of Azerbaijan, then giving policy recommendation based on the results of the research.

There are two significant contributions that are to be derived from the outcome of this study. First, It analyzes the effectiveness of monetary policy tools in Azerbaijan case, which is a rarely investigated topic including recent years' data and it could be a good measure for the economies similar to Azerbaijan. Furthermore, this is the first research paper investigating the effectiveness of monetary policy tools in Azerbaijan by running standard Granger causality and impulse-response tests under VAR approach, which enables us to observe the country-specific attribute of this issue.

Within this context, at first, similar studies related to the research topic will be explained in the literature review section. Later in the paper, econometric method, data and findings will be thoroughly analyzed. In the final part of the study, results of analysis and recommendations derived from obtained research outcomes will be presented.

\section{Literature Review}

In this part, the recent studies in which main aims are to analyze the relationship between monetary policy and economic growth are reviewed. It is concluded that because of the importance of the topic there are a vast number of studies which are devoted to investigating the relationship between economic growth and monetary policy.

In the context of monetary policy and economic growth, Dilshad Ahmed et al., (2016) examined the existence of a link between monetary policy and economic growth in Pakistan employing Autoregressive Distribution Lag (ARDL) to the data spanning from 1973 to 2014 . The empirical outcomes indicate that there is a statistically significant long-run relationship between money supply and exchange rate, which positively affects economic growth. By using Vector Auto Regressive (VAR) model, Berument and Dincer (2008) investigated monetary policy vitality in Turkish economy and findings summarize that monetary policy has a temporary effect on output, whereas it has a lasting effect on prices.

Ali et al (2008) in their study for Southeast Asian countries, analyzed the effects of monetary and fiscal policy on economic growth. The effect of money supply on economic growth both in the short and long term was found to be positive in the study conducted using the ARDL boundary test. It is observed that fiscal policy has no effect on economic growth both in short and long term. As a result, it is revealed that the economic growth-enhancing effect of monetary policy is much higher than fiscal policy.

Yucel (2009) for 1989 and 2007, using monthly data in his study of economic growth has studied the relationship between trade openness and financial development. In the analysis, while there is a negative link between financial improvement and economic growth, there is also a positive link between openness and economic growth. In Granger causality analysis, a two-way relationship was found between financial development, openness and economic growth.

In Muhammad's (2009) study for Pakistan, M2 was examined with the help of the VAR model, whether there is a long-term relationship between public expenditures and economic growth. In the cointegration analysis, while there was a negative relationship between public expenditures and M2, a positive relationship was also found between M2 and economic growth. Ogunmuyiwa and Ekone (2010) with the least-squares method and error correction model in Nigeria, a positive effect of the increase in money supply on economic growth has been determined. By using cointegration and VAR analyzes for the Pakistani economy, Jawaid et al. (2010) showed that the effect of monetary policy on economic growth was positive in the long-run and more effective than fiscal policy. Sakyi (2011), analyzed the same variables in his study for Ghana and concluded that there was a positive relationship between external openness, economic growth and external aid in both short and long term. In this analysis, he found that public expenditures had a statistically significant negative effect on economic growth of the country.

In the study of Fasanya, Onakoya and Agboluaje (2013), the relationship between monetary policy and economic 
growth was investigated for 1975-2013. As a result of the Var analysis, a long-term cointegration between monetary policy and economic growth emerged.

In the research done by Chipote and Makhetha-Kosi (2014), the relationship between monetary policy and economic growth was examined for South Africa and it was found that there was a positive relationship between monetary policy and economic growth in the long period of time. In other words, the long-term monetary policy affects economic growth. Yildirim (2013) in Turkey, South Africa, Brazil, China, India and Russia based on a sample comprising six countries formed the structural VAR model. In this situation, outcomes indicated that the implementation of the tight monetary policy has a negative impact on inflation and growth through interest rates. So the government can oversee the inflation and economic activities by monetary policy.

There are few investigations which are somehow related to the link between monetary policy and economic growth in Azerbaijan as well. Mukhtarov et al. (2016) analyzed the influence of monetary policy tools on production and prices by using VECM (Vector Error Correction Model) for the period span of 2001:4-2014:3. Findings clarify both credit and interest channels are significant factors in Azerbaijan economy. A study by Hasanov (2011), analyzed two main macroeconomic variables, inflation and economic growth, in Azerbaijan for the period of 2000-2009. Results of the investigation reveal that there is non-linear association between inflation and economic growth in Azerbaijan, More precisely, there is a 13\% threshold level of inflation and below this threshold level there is a statistically significant positive relationship between inflation and economc growth, but over this threshold level there is a negative relationship between the variables. This can help to monetary policymakers to hold inflation below threshold level of $13 \%$ to avoid from its negative effect on GDP growth. According to the findings of Duzgun (2010) using the ARDL (Autoregressive Distributed Lag) method, monetary policy has a positive effect but it is not statistically significant to affect the Azerbaijani economy, but on the other hand public expenditure has a negative and significant effect. An expanding monetary policy is stimulating the economy, while an expanding fiscal policy narrows the economy. The budget deficit caused by the expansionary fiscal policy will reduce private investment through interest rates and reduce the economy. The findings in both directions suggest that the Monetarist view is valid. However, the fact that the variable representing monetary policy is meaningless reveals that monetary policy is ineffective on the economy. As a result, fiscal policy is more effective in the economy of Azerbaijan. The existence of supportive results of the monetarist view has emerged. But there are some exceptional cases. The most important reason for this is the economic situation of the country, the method used in the analysis and the characteristics of the selected data.

As a result of these researches, it can be concluded that in each country the link between monetary policy and economic growth differs. But the question is how the link is in Azerbaijan including most recent data.

\section{Methodology and Data}

For the purpose of empirical analysis, the study employs monthly data over the period of April 2005 to December 2018 in Azerbaijan for the variables which are monetary base (M), non-oil GDP (NGDP), discount rate (INT) and real exchange rate (EXC). All data sets were taken from the Central Bank of the Republic of Azerbaijan. (CBAR, $2018 \mathrm{a}$ and b). Non-oil GDP is the dependent variable in the model. The non-oil GDP is measured by the monetary value of non-oil sector output deflated by the consumer price index (CPI). Monetary base (M) for Azerbaijan which includes the total amount of currencies and the commercial bank deposits held in the central bank's reserves is measured in billion AZN and is one of the main independent variables. In many previous studies for relatively small and resource-rich countries such as Havi and Enu (2014) for Ghana, Kareem et al. (2013) for Nigeria, Dilshad Ahmad et. al. (2016) for Pakistan, Nouri and Samimi (2011) for Iran, Moursi and El Mossallamy (2010) for Egypt money supply was found to have significant impact on economic growth. Moreover, previous papers, such as Berument and Dincer (2008), Ogunmuyiwa and Ekone (2010), Ali et. al. (2008) found that higher money supply would increase economic growth. Considering the result of the mentioned studies of similar economies, it is plausible to test whether money supply is also a driver of economic growth in Azerbaijan or not. Discount rate or interest rate applied by the central bank to other banks, when lending loans is another independent variable in the model. Other researches like Werner and Lee (2018), Baum et. al. (2012), found the existence of a higher link between interest rate and economic growth. Due to the fact that Azerbaijan had two significant devaluations in February and December of 2015. Also, it is a fact that the Central Bank of Azerbaijan considers the exchange rate as a very important indicator and widely utilizes it in its policy implications. (Hasanov (2018) Considering above-mentioned facts, the real exchange rate (EXC) was also employed as a control variable in our study, which could have an effect on economic growth. The EXC was measured in national currency per US dollar. This variable was used in many previous researches such as Egert (2009), Hasanov (2010), Sturm et. al. (2009) and Mukhtarov 
et.al. (2018) that showed that exchange rate had a significant effect on essential macroeconomic indicators. All the variables that are used in the model are transformed into the natural logarithmic form.

By using different cointegration tests, the existence of the relationship among non-oil GDP, monetary base, discount rate and exchange rate are examined in the study. In the empirical part, first, unit roots of variables are examined. Then based on the results of unit root tests it is determined whether the variable series are stationary or not. After that, the existence of long run relationships among non-oil GDP, monetary base, discount rate and exchange rate are tested and at last the long run model among these variables is estimated. Augmented Dickey Fuller (ADF) tests by Dickey and Fuller (1981) are employed to examine stationarity of variable series. While analyzing cointegration relationships among variables, Johansen (1988) cointegration test is utilized in the beginning. Next, other four cointegration methods are used to examine long run relationships. These equations are Vector Error Correction Model (VECM) which is employed as the main equation, Fully Modified Ordinary Least Squares Method (FMOLS), Canonical Cointegrating Regression (CCR) and Dynamic Ordinary Least Squares (DOLS). They are all operated for the purpose of robustness check. At the end, the coefficients of regression models were interpreted and useful information was derived for Azerbaijan

The methods utilized above are used intensively in many studies. The elaborate information about these methods were mentioned in Dickey and Fuller (1981), Engle and Granger (1987), Johansen (1988), Stock and Watson (1993), Park (1992) and others.

\section{Empirical Estimations and Results}

First, stationarity of variables series that are used in the model must be examined. As it was stemmed in methodology part, Augmented Dickey-Fuller (ADF) test which was developed by Dickey and Fuller (1981) was employed to test whether variable series are stationary or not. All outcomes of ADF test were summarized in Table 1. In the ADF tests, maximum lag order was selected by Schwarz Information Criterion (SIC). Both trend and intercept were taken into consideration while operating ADF tests.

Table 1. Results of ADF unit root tests

\begin{tabular}{crcr}
\hline \multirow{2}{*}{ Variable } & \multicolumn{2}{l}{$\begin{array}{l}\text { Panel A: } \\
\text { Level }\end{array}$} & \multicolumn{2}{l}{$\begin{array}{l}\text { Panel B: } \\
\text { 1st difference }\end{array}$} & Result \\
\cline { 2 - 4 } & \multicolumn{2}{c}{ Actual value } & Actual value \\
\hline$N G D P$ & -0.6597 & $-3.6069^{* * *}$ & $\mathrm{I}(1)$ \\
$M$ & -1.0980 & $-9.6469^{* * *}$ & $\mathrm{I}(1)$ \\
$I N T$ & -1.6102 & $-9.0521^{* * *}$ & $\mathrm{I}(1)$ \\
$E X C$ & -1.2750 & $-8.6978^{* * *}$ & $\mathrm{I}(1)$
\end{tabular}

Notes: Maximum lag order is set to two and optimal lag order (k) is selected based on Schwarz criterion in the $\mathrm{ADF}$ test; *,** and *** accordingly indicates rejection of null hypothesis at $10 \%, 5 \%$ and $1 \%$ significance levels; critical values are taken from the table prepared by MacKinnonun (1996). Time period: 2005:M1-2018:M12.

Based on the outcomes of ADF tests shown in Table 1, it was found that the first differenced form of non-oil GDP, real exchange rate, discount rate and money supply have no unit roots. As a result of the ADF test, all variable series were found to be I(1) or in other terms, stationary at first differenced form. These findings permit us to estimate long-run relationships among variables. Then, as a next step, based on the results of unit root tests, we can pass to the next phase of our empirical investigation and proceed to cointegration tests.

To operate Johansen cointegration test, first optimal lag number must be chosen. For the purpose of choosing optimal lag number for variables, lag length selection criteria under VAR (Vector Autoregression) model should be utilized. By estimating Vector Autoregression (VAR) among variables and using lag length selection criteria under VAR model, we can clearly examine which lag number is appropriate for the data.

VAR lag length selection criteria result is summarized in Table 2. In Table 4, the result of five information criteria was shown. According to the outcomes of the VAR lag length selection criteria, 3 lags were chosen. This is because three of the Lag interval test criteria which are sequential modified LR test statistic (each test at 5\% level), Final Prediction Error (FPE), Akaike information criterion (AIC) suggest to select 3 lags. Only other 2 test criteria (HQ: Hannan-Quinn information criterion and SC: Schwarz information criterion) suggest to selection of 2 lags. 
Table 2. Lag Length Selection Criteria Tests

\begin{tabular}{lccccrrr}
\hline \multicolumn{7}{c}{ Information Criteria } \\
\hline Lag & LogL & LR & FPE & AIC & SC & HQ \\
\hline 1 & 277.7792 & NA & $4.83 \mathrm{e}-07$ & -3.192429 & -2.890003 & -3.069656 \\
& & & & -3.074042 & \\
2 & 333.6693 & 106.3275 & $2.97 \mathrm{e}-07$ & -3.678894 & $*$ & $-3.433347^{*}$ \\
3 & 351.0105 & $32.14473^{*}$ & $2.92 \mathrm{e}-07 *$ & $-3.695250^{*}$ & -2.787972 & -3.326930 \\
4 & 359.1531 & 14.69627 & $3.22 \mathrm{e}-07$ & -3.599427 & -2.389723 & -3.108333 \\
\hline
\end{tabular}

* indicates lag order selected by the criterion, LR: sequential modified LR test statistic (each test at 5\% level), FPE: Final prediction error, AIC: Akaike information criterion, SC: Schwarz information criterion, HQ: Hannan-Quinn information criterion

Diagnostic test results for residuals and Johansen cointegration test outcomes were summarized in Table 3 .

Regarding Part A of Table 3, null hypothesis claims that there is no autocorrelation among error terms and p-value is more than 5\%. Therefore there is no serial correlation or autocorrelation among residual series. Analogically, the outcomes of heteroscedasticity and normality test for error terms in Panel B and C of Table 3 state that the residuals are normally distributed and there is no heteroscedasticity problem in the model. VAR stability test results in Panel D of Table 3 conclude that all roots of characteristic polynomial are inside of the unit circle which means the VAR model is stable. The outcomes of these tests show that the VAR model is reliable.

Johansen cointegration test was utilized to examine the existence of long-run relationships. Outcomes derived from Johansen cointegration test are presented in Panel E and F of Table 3. From the Johansen cointegration test results, there is no sufficient evidence to reject the hypothesis of one cointegration relationship. In other terms, both the trace and the max-eigenvalue test statistics in Johansen Cointegration Rank Test indicate one cointegration relationship. In this regard, it can be concluded that there is a cointegrating relationship among the indicated variables.

Table 3. VAR residual diagnostics, stability and cointegration tests results

\begin{tabular}{|c|c|c|}
\hline \multicolumn{3}{|c|}{ Panel A: LM test for Serial Correlation } \\
\hline Lags & LM-Statistic & $\mathrm{P}$-value \\
\hline 1 & 14.567 & 0.5565 \\
\hline 2 & 17.056 & 0.3819 \\
\hline 3 & 15.950 & 0.4564 \\
\hline \multirow{2}{*}{\multicolumn{3}{|c|}{$\frac{4}{\text { Panel B: Normality Test }} \mathbf{b}^{\mathbf{b}}$}} \\
\hline & & \\
\hline Statistic & d.f. & Pvalue \\
\hline Jarque-Bera & 7.3515 & 0.118 \\
\hline \multicolumn{3}{|c|}{ Panel C: Test for Heteroscedasticity ${ }^{\mathbf{c}}$} \\
\hline White & d.f. & $\mathrm{P}$ value \\
\hline Statistic & 186.11 & 0.077 \\
\hline \multicolumn{3}{|c|}{ Panel D: Test for Stability } \\
\hline Modulus & \multicolumn{2}{|r|}{ Root } \\
\hline 0.638833 & $0.336702 \mathrm{i}$ & $\begin{array}{l}00- \\
2 \mathrm{i}\end{array}$ \\
\hline 0.638833 & \multicolumn{2}{|c|}{$0.336702 \mathrm{i}$} \\
\hline 0.466035 & \multicolumn{2}{|c|}{$\begin{array}{l}0.158324+ \\
0.438318 \mathrm{i}\end{array}$} \\
\hline
\end{tabular}

\begin{tabular}{ccccc}
\hline \multicolumn{6}{c}{ Panel E: Johansen Cointegration Rank Test (Trace) } \\
\hline $\begin{array}{c}\text { Null } \\
\text { hypothesis }\end{array}$ & Eigenvalue & $\begin{array}{c}\text { Trace } \\
\text { statistics }\end{array}$ & $\begin{array}{c}0.05 \\
\text { Critical value }\end{array}$ & P-value \\
\hline None & 0.275261 & 0.275261 & 47.85613 & 0.0000 \\
At most 1 & 0.078720 & 0.078720 & 29.79707 & 0.2603 \\
At most 2 & 0.054127 & 0.054127 & 15.49471 & 0.3483 \\
\hline At most 3 & $3.55 E-05$ & $3.55 E-05$ & 3.841466 & 0.9383 \\
\hline \multicolumn{5}{l}{ Panel F: Johansen Cointegration Rank Test (Maximum Eigenvalue) } \\
Null & Eigenvalue & Max-Eigen & 0.05 Criticial & P-value \\
hypothesis: & Statistic & value & 0.0000 \\
None * & 0.275261 & 53.12073 & 27.58434 \\
At most 1 & 0.078720 & 13.52859 & 21.13162 & 0.4049 \\
At most 2 & 0.054127 & 9.181706 & 14.26460 & 0.2713 \\
\hline At most 3 & $3.55 E-05$ & 0.005854 & 3.841466 & 0.9383 \\
\hline \multicolumn{5}{c}{}
\end{tabular}


To run a long-run relationship among variables, we utilized the Vector Error Correction Model (VECM) as the main model. In order to match all regression assumptions, all tests related to residuals were done in VECM. The outcomes of residuals diagnostic tests present that residuals are normal, stable and there is homoscedasticity. As all assumptions about residuals are satisfied, it can be stemmed that the Vector Error Correction Model in this case is reliable.

Table 4. Outcomes of tests from the different cointegration methods

\begin{tabular}{|c|c|c|c|c|}
\hline Method & VECM & DOLS & CCR & FMOLS \\
\hline & & \multicolumn{3}{|c|}{ Panel A: Long-run equations } \\
\hline Regressor & Coef.(Std. Er.) & Coef. (Std. Er.) & Coef. (Std. Er.) & Coef. (Std. Er.) \\
\hline M & $0.52(0.09) * * *$ & $0.60(0.10) * * *$ & $0.58(0.90) * * *$ & $0.58(0.09) * * *$ \\
\hline INT & $-0.03(0.03)$ & $-0.04(0.03)$ & $-0.03(0.02)$ & $-0.03(0.02)$ \\
\hline EXC & $1.01(0.36) * *$ & $1.09(0.38) * * *$ & $1.02(0.35) * * *$ & $1.02(0.35) * * *$ \\
\hline \multicolumn{2}{|c|}{ 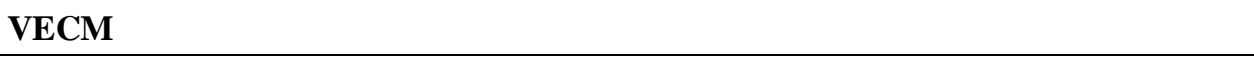 } & \multicolumn{3}{|c|}{ Panel B: Residuals diagnostics tests results for } \\
\hline$Q_{A R(2)}$ & \multicolumn{4}{|l|}{$2.54[0.863]$} \\
\hline$L M_{S C}$ & \multicolumn{4}{|l|}{$1.04[0.409]$} \\
\hline$\chi_{\text {HETR }}^{2}$ & \multicolumn{4}{|l|}{$103.6[0.072]$} \\
\hline$J B_{N}$ & \multicolumn{4}{|l|}{$4.46[0.346]$} \\
\hline \multicolumn{5}{|c|}{$\begin{array}{l}\text { Notes: Dependent variable is NGDP; Coef. and Std. Er. denote coefficient and standard } \\
\text { error; * ** and *** indicate significance levels at } 10 \%, 5 \% \text { and } 1 \% \text {; Probabilities are in } \\
\text { brackets; } Q_{A R(2)}=\text { Q-statistic from testing AR(2) process; } L M_{S C}=\text { Lagrange multiplier } \\
\text { statistic of serial correlation test; } \chi_{H E T R}^{2}=\text { Chi-squared statistic for heteroscedasticity } \\
\text { test; } J B_{N}=\text { Jarque-Bera statistic for testing normality; In VECM, Jarque-Bera statistic } \\
\text { was taken from the option of Orthogonalization: Residual Correlation (Doornik-Hansen). }\end{array}$} \\
\hline
\end{tabular}

Besides VECM, with the intention of robustness check, we also employed DOLS, FMOLS and CCR methods among variables (see table 4). There we compared all results and found out that all methods provided almost identical results in coefficient and in sign. The results of these tests indicate that Money supply and exchange rate have a significant effect on non-oil GDP, while the impact of the discount rate which is offered by the Central Bank of Azerbaijan Republic to other commercial banks is statistically insignificant. The results in the main model, VECM, also indicate that a $1 \%$ increase in monetary base will have $0.52 \%$ increase in non-oil GDP. Having significant positive impact of $\mathrm{M}$ on economic growth, our findings are consistent with the outcomes of Berument and Dincer (2008), Dilshad Ahmad et. al. (2016), Ogunmuyiwa and Ekone (2010), Ali et al. (2008), Moursi and El Mossallamy (2010). We also found that a $1 \%$ increase in real exchange rate will lead to $1.01 \%$ increase in non-oil GDP. This is in accordance with economic theory. Because in theory an increase in exchange rate will cause depreciation of national currency and it will lead to increase in net exports. Eventually, an increase in net exports will lead to increase in GDP.

\section{Conclusion and Recommendation}

To regulate economic situations, monetary policy is a very useful tool in any economy. In Azerbaijan, several monetary policy tools have been employed recently with the aim of obtaining economic stability. In addition to this, several devaluations (February 2015 and December 2015) were implemented with the purpose of increasing the value of oil and non-oil exports. This predicted increase in net exports would also affect GDP. But the interesting question is how effective these policy tools are in Azerbaijan's economic growth.

First, the variables were tested for the unit root and based on the results all series were found to be stationary at first differenced form. In this case, the variables could be examined for a common long-run trend. The Johansen 
cointegration test concluded the existence of a cointegration relationship among the variables. This implies that there is a long-run relationship between monetary base, non-oil GDP, discount rate and real exchange rate. The VECM approach was utilized to estimate the long run relationship among these economic indicators. The estimation outcome of VECM shows that the monetary base and the exchange rate have a significant positive impact on economic growth. However, the effect of interest rate is insignificant.

As a result of this study, it can be recommended that further essential legal and institutional affairs should be carried out for the solution of the problematic assets issues in the banking sector to make sure more efficient operation of monetary policy tools in Azerbaijan. Furthermore, by developing and diversifying non-bank financial institutions, providing alternative borrowing opportunities for bank loans, increasing the competitive environment in the banking system, further increasing risk measurement and evaluation activities of loans, conducting effective audits, altering loan and deposit contracts so that the payments related to those loans should be adjusted for variables such as inflation and exchange rate and economic factors. At last, the Central Bank of Azerbaijan (CBAR) should use the communication policy effectively in order to direct the expectations of the people and firms.

\section{References}

Ali, F. D., Kenneth, A. T., \& Cedric, L. M. (2008). Whether Fiscal Stance or Monetary Policy is Effective for Economic Growth in Case of South Asian Countries?. The Pakistan Development Review, 47, 241-254.

Baum, A., Westphal, C., \& Rother, P. (2012). Debt And Growth: new Evidence for the Euro Area. Eurpoean Central Bank, Working Paper series No 1450.

Berument, M. H., \& Dincer, N. (2008). Measuring The Effects of Monetary Policy for Turkey. Journal of Economic Cooperation, 29, 83-100.

CBAR. (2018a). Retrieved March 5, 2019, from https://www.cbar.az/page-42/monetary-indicators\#page-2

CBAR. (2018b). Retrieved March 5, 2019, from https://www.cbar.az/page-41/macroeconomic-indicators

Chipote, P., \& Makhetha-Kosi, P. (2014). Impact of Monetary Policy on Economic Growth: A Case Study of South Africa. Mediterranean Journal of Social Sciences, 5, 76-84.

Dickey, D., \& Fuller, W. (1981). Likelihood Ratio Statistics for Autoregressive Time Series with a Unit Root. Econometrica, 49, 1057-1072.

Dilshad, A., Afzal, M., \& Khan, U. (2016). Impact of Monetary Policy on Economic Growth Empirical Evidence of Pakistan. International Journal of Applied Economic Studies, 4.

Duzgun, R. (2010). Effectiveness of Monetary and fiscal policy in Turkey Economy. International Social Research Journal, 3, 230-237

Egert, B. (2009). The Impact of Monetary and Commodity Fundamentals, Macro News and Central Bank Communication on the Exchange Rate: Evidence from South Africa. OECD Economics Department Working Papers, No. 692, OECD Publishing.

Engle, R. F., \& Granger, C. W. J. (1987). Co-integration and error correction: representation, estimation and testing. Econometrica, 55, 251-276.

Fasanya, I. O., Onakoya, B. O., \& Agboluaje, M. A. (2013). Does Monetary Policy Influence Economic Growth in Nigeria?. Asian Economic and Financial Review, 3, 635-646.

Hameed, G., Khaid, M., \& Sabit, R. (2012). Linkage between Monetary Instruments and Economic Growth. Universal Journal of Management and Social Sciences, 2, 69-76.

Hasanov, F. (2011). Relationship between Inflation and Economic Growth in Azerbaijani Economy: Is There Any Threshold Effect?. Asian Journal of Business and Management Sciences, 1, 1-11.

Hasanov, F., \& Samadova, I. (2010). The impact of real effective exchange rate on the non-oil export: The case of Azerbaijan. MPRA, Paper No. 79559

Hasanov, R. (2018). The exchange rate outlook in Azerbaijan in 2018: Expectations and Challenges. Center for Economic and Social Development (CESD), Baku.

Havi, E. D. K., \& Enu, P. (2014). The Effect of Fiscal Policy and Monetary Policy on Ghana's Economic Growth: Which Policy Is More Potent?. International Journal of Academic Research in Business and Social Sciences, 4(7), 95-110. 
Jawaid, S. T., Imtiaz, A., \& Naeemullah, S. M. (2010). Comparative Analysis of Monetary and Fiscal Policy: A Case Study of Pakistan. Nice Research Journal, 3, 58-67.

Johansen, S. (1988). Statistical analysis of cointegration vectors. Journal of Economic Dynamics and Control, 12, 232-255.

Kareem, R. O., Afolabi, A. J., Raheemand, K. A., \& Bashir, N. O. (2013). Analysis of Fiscal and Monetary Policies on Economic Growth: Evidence from Nigerian Democracy. Current Research Journal of Economic Theory, 5(1), 11-10.

Mackinnon, J. G. (1996). Numerical Distribution Functions for Unit Root and Co-integration Test. Journal of Applied Econometrics, 11, 601-618.

Mammadov, Z. (2013). Principles of banking. Azer Neshriyat.

Mankiw, N. G. (2012). Macroeconomics. Worth Publishers.

Moursi, T., \& Mossallamy, M. (2010). Monetary Policy Response to Exchange Rate Movements: The case of Egypt. ECES working paper Nr. 158.

Muhammad, S. D., Wasti, S. K., \& Hussain, A. (2009). An Empirical Investigation between Money Supply, Government Expenditure, Output and Price: The Pakistan Evidence. European Journal of Economics, Finance and Administrative Sciences, 17, 60-69.

Mukhtarov, S., \& Mikhayllov, J. (2016). Testing Of Monetary Policy Transmission Mechanisms in the Case of Azerbaijan. Qafqaz-Economics and Management, 1, 103-109.

Mukhtarov, S., Gasimov, I., \& Rustamov, U. (2018). Evaluation of fiscal policy impact on economic growth: the case of Azerbaijan. ASERC Journal of Socio-Economic Studies, 1, 82-90.

Nouri, M., \& Samimi, A. J. (2011). The Impact of Monetary Policy on Economic Growth in Iran.

Ogunmuyiwa, M. S., \& Ekone, A. F. (2010). Money Supply - Economic Growth Nexus in Nigeria. Journal of Social Science, 22, 199-204.

Park, J. Y. (1992). Canonical cointegrating regressions. Econometrica, 60, 119-143.

Sakyi, D. (2011). Trade Openness, Foreign Aid and Economic Growth in Post-Liberalisation Ghana: An Application of ARDL Bound Test. Journal of Economics and International Finance, 3, 61-75.

Schmitt-Grohe, S., \& Uribe, M. (2007). Optimal simple and implementable monetary and fiscal rules. Journal of Monetary Economics, 54, 1702-1725.

Stock, J. H., \& Watson, M. (1993). A simple estimator of cointegrating vectors in higher order integrated systems. Econometrica, 61, 783-820.

Sturm, M., Gurtner, F., \& Alegre, J. G. (2009). Fiscal policy challenges in oil-exporting countries: A review of key issues. European Central Bank, Occasional paper series No. 104.

Urzua, C. M. (1997). Omnibus Tests for Multivariate Normality of Observations and Residuals. Advances in Econometrics, 12, 341-358.

Werner, R. A., \& Lee, K. S. (2018). Reconsidering Monetary Policy: An Empirical Examination of the Relationship Between Interest Rates and Nominal GDP Growth in the U.S., U.K., Germany and Japan. Elsevier, 146, 26-34.

Yildirim, Z. (2013). Monetary Policy Shocks and Macroeconomic Variables: Evidence from Fast Growing Emerging Economies. Economics, 6, 2-26.

Yucel, F. (2009). Causal Relationships between Financial Development, Trade Openness and Economic Growth: The Case of Turkey. Journal of Social Sciences, 5, 33-42. 